\title{
INDEKS PENGARANG
}

Agus Tinus

Ahmad Arif W

Anita Dwi Agustin

Budiono

Eka Nur Cahyaning Asih

Fahdian Rahmandani

Fitrianur Widya Ningrum

M. Mansur Ibrahim

M. Syahri

Moh Salahuddin
18 Moh. Wahyu K 62

92 Nurbani Yusuf 52

1 Nurul Zuriah 9

9 Rini 62

9 Rohmad Widodo 102

18 Rose Fitria L 92

45 Rosmiati 75

18 Sahrani Rizal 102

1 Syahrul Hadiyatullah 111

52 Trisakti Handayani 75 


\section{Petunjuk Penulisan Artikel JURNAL CIVIC HUKUM}

\section{Ketentuan Umum}

1. Yang dimaksud dengan "Naskah" dalam pedoman ini adalah hasil penelitian dan studi perpustakaan memusatkan perhatian pada masalah kewarganegaraan, Pendidikan Karakter, Hukum, Politik, Pendidikan Antikorupsi, dan Pembelajaran Kewarganegaraan.

2. Penulis naskah wajib membuat dan menandatangani surat pernyataan bermaterai yang menyatakan bahwa naskah yang ditulis merupakan hasil karya sendiri dan belum pernah dipublikasikan di media lain.

3. Naskah dapat di diunggah dan register lebih dulu melalui laman website : http://ejournal.umm.ac.id/index.php/jurnalcivichukum/user/register

\section{Ketentuan Penulisan Naskah}

1. Bahasa yang digunakan dalam penulisan naskah adalah Bahasa Indonesia atau Bahasa Inggris.

2. Naskah diketik di atas kertas A4 dengan margin kiri $4 \mathrm{~cm}$, margin atas, bawah dan kanan $3 \mathrm{~cm}$, menggunakan tipe huruf Times New Roman, ukuran huruf 12, dan spasi 1.

3. Jumlah halaman naskah adalah 10 sampai dengan 15 halaman.

4. Sistematika Penulisan:

a. JUDUL [Times New Roman 14 bold]

Penulisan judul menggunakan kalimat singkat, namun cukup untuk menggambarkan isi (substansi) naskah secara keseluruhan. Judul tulisan berbahasa Indonesia terdiri dari maksimal 14 kata, sedangkan apabila berbahasa Inggris terdiri dari maksimal 12 kata.

b. Nama Penulis [Times New Roman 12 bold]

Nama penulis dicantumkan tanpa gelar, kemudian disertai alamat korespondensi (instansi), dan alamat surat elektronik (email). Apabila terdapat lebih dari satu penulis maka dituliskan seperti penulis Utama. Untuk penulis utama harap menyertakan nomor HP yang bisa dihubungi.

c. ABSTRAK dan Kata Kunci [Times New Roman 10 bold] Abstrak terdiri dari maksimal 200 kata. Abstrak mencerminkan permasalahan, tujuan, metode penelitian, hasil dan saran. Abstrak ditulis dalam Bahasa Indonesia dan Bahasa Inggris, menggunakan huruf jenis Times New Roman ukuran 10, spasi 1. Kata kunci disusun secara alfabetis, mencerminkan kandungan esensi artikel, dibuat sejumlah 3-5 kata/frase.

d. PENDAHULUAN [Times New Roman 12 bold]

Pendahuluan (berisi latar belakang, konteks penelitian, hasil kajian pustaka, dan tujuan penelitian, yang semuanya dipaparkan secara terintegrasi dalam 
bentuk paragraf-paragraf, dengan persentase $15-20 \%$ dari keseluruhan artikel) Tinjauan pustaka yang relevan dan pengembangan hipotesis (jika ada) dimasukkan dalam bagian ini. [Times New Roman, 12, normal].

e. METODE [Times New Roman 12 bold]

Metode menjelaskan paparan dalam bentuk paragraf tentang rancangan penelitian, sumber data, teknik pengumpulan data, dan analisis data yang secara nyata dilakukan peneliti, dengan persentase 10-15\% [Times New Roman, 12, normal].

f. HASIL dan PEMBAHASAN [Times New Roman 12 bold]

Hasil penelitian berisi paparan hasil analisis yang berkaitan dengan pertanyaan penelitian, sedangkan pembahasan berisi pemaknaan hasil dan perbandingan dengan teori dan/atau hasil penelitian sejenis, dengan persentase $40-60 \%$ dari keseluruhan artikel); Kemungkinan tindak lanjut kegiatan dapat juga disampaikan pada bagian ini Hasil penelitian dapat dilengkapi dengan tabel 1 (bukan tabel berikut:), grafik/gambar 1 (bukan grafik/gambar berikut: ), dan/atau bagan 1 (bukan bagan berikut: ). [Times New Roman, 12, normal].

Tabel 1. Nama Tabel (contoh tabel 1)

\begin{tabular}{lccc}
\hline & & \multicolumn{2}{c}{ 95\%CI } \\
\cline { 3 - 4 } Condition & $M(S D)$ & LL & UL \\
\hline Letters & $14.5(28.6)$ & 5.4 & 23.6 \\
Digits & $31.8(33.2)$ & 21.2 & 42.4 \\
\hline
\end{tabular}

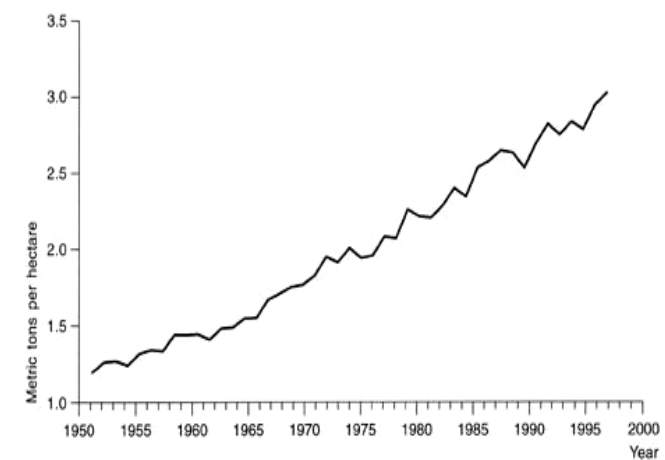

Gambar 1. Nama gambar (contoh gambar 1)

g. SIMPULAN [Times New Roman 12 bold]

Berisi temuan penelitian yang berupa jawaban atas pertanyaan penelitian atau berupa intisari hasil pembahasan, yang disajikan dalam bentuk paragraf . Saran dapat disampaikan pada bagian ini [Times New Roman, 12, normal].

h. Daftar Pustaka.

Daftar Pustaka ditulis dengan sistematika dan ditulis secara berurut sesuai abjad. Tanda baca koma diganti dengan tanda baca titik; tidak dicantumkan halaman kutipan; kutipan yang ada dalam batang tubuh (artikel) wajib 
dicantumkan di daftar pustaka begitu juga sebaliknya kutipan yang ada dalam daftar pustaka wajib ada di batang tubuh (artikel).

\section{Rujukan Buku:}

Noddings, N. 1993. Educating for Intelligent Belief or Unbelief. New York: Teacher College Press.

\section{Rujukan Artikel dalam Buku Kumpulan Artikel}

Margono. 2008. Manajemen Jurnal Ilmiah. Dalam M.G Waseso \& A. Saukah (Eds.), Menerbitkan Jurnal Ilmiah (hlm. 46-50). Malang: UMM Press.

\section{Rujukan Berupa Buku yang Ada Editornya}

Rusli, Marah. 2005. Sosiologi Pendidikan: Kajian Berdasarkan Teori Integritas Mikro-Makro (Arnaldi. S Ed.) Malang: UMM Press.

\section{Rujukan dari Buku yang Berasal dari Perpustakaan Elektronik}

Dealey, C. 1998. The Care of Wounds: A Guide for Nurses. Oxford: Blackwell Science. Dari NetLibrary, (Online), (http://netlibrary.com), diakses 26 Agustus 2012.

\section{Rujukan dari Artikel dalam Internet Berbasis Jurnal Tercetak}

Mappiare-AT, A., Ibrahim, A.S. \& Sudjiono. 2009. Budaya Komunikasi RemajaPelajar di Tiga Kota Metropolitan Pantai Indonesia. Jurnal Ilmu Pendidikan, (Online), 16 (1): 12-21, (http://www.umm.ac.id) diakses 28 Oktober 2009

\section{Rujukan dari Artikel dalam Jurnal dari CD-ROM}

Krashen, S., Long, M. \& Scarcella, R. 2007. Age, Rate and Evantual Attainment in Second Language Acquisition. TESOL Quarterly, 13: 543-567 (CDROM: TESOL Quarterly-Digital, 2007).

\section{Rujukan Artikel dalam Jurnal atau Majalah:}

Wentzel, K. R. 1997. Student Motivation in Middle School: The Role of Perceived Pedagogical Caring. Journal of Educational Psychology, 89 (3), 411-419.

\section{Buku Terjemahan:}

Habermas , Jurgen. 2007. Teori Tindakan Komunikatif II: Kritik atas Rasio Fungsionaris. Terjemahan oleh Nurhadi. Yogyakarta: Kreasi Wacana.

Rujukan dari Dokumen Resmi Pemerintah yang diterbitkan oleh Lembaga tersebut

Undang-Undang Sistem Pendidikan Nasional (UURI No. 20 Tahun 2003 dan Peraturan Pelaksanaannya. 2003. Jakarta: Departemen Pendidikan Nasional.

\section{Rujukan dari Koran tanpa penulis}

Jawa Pos, 27 Mei 2015. "Komitmen Mendikbud Segarkan Pramuka”. Halaman 3. 


\section{Rujukan dari Internet:}

Winingsih, H. Lucia. 2007. Peningkatan Mutu, Relevansi dan Daya Saing Pendidikan. Jakarta: Pusat Dokumentasi dan Informasi Ilmiah-Lembaga Ilmu Pengetahuan Indonesia PDII-LIPI, diakses 2 Desember 2014 on-line www. Pdii.lipi.go.id/katalog/index. php/search catalog /byld/257453.

\section{Rujukan Berupa Skripsi, Tesis, atau Disertasi.}

Mulyana, Yoyo. 2000. Keefektifan Model Mengajar Respons Pembaca dalam Pengajaran Pengkajian Puisi. Disertasi tidak Diterbitkan. Bandung: Fakultas Fakultas Bahasa dan Seni Universitas Pendidikan Indonesia.

Musaffak. 2013. Peningkatan Kemampuan Membaca Kritis dengan Menggunakan Metode Mind Mapping. Tesis tidak Diterbitkan. Malang: PPs UM.

5. Pustaka acuan yang digunakan adalah maksimal 10 tahun terakhir dengan jumlah minimal 10 buah dan minimal $50 \%$ diantaranya berasal dari jurnal ilmiah.

6. Redaktur berhak mengubah tulisan pada naskah sepanjang tidak mempengaruhi materi atau isi pokok pembahasan.

7. Segala sesuatu yang menyangkut perizinan pengutipan atau penggunaan software komputer untuk pembuatan naskah atau ihwal lain yang terkait dengan HaKI yang dilakukan oleh penulis artikel, berikut konsekuensi hukum yang mungkin timbul karenanya, menjadi tanggung jawab penuh penulis artikel. 


\title{
JUDUL DITULIS DENGAN \\ FONT TIMES NEW ROMAN 14 CETAK TEBAL (MAKSIMUM 14 KATA)
}

\author{
Penulis1 $^{1)}$, Penulis2 ${ }^{2)}$ dst. [Font Times New Roman 12, tanpa gelar dan \\ Tidak Boleh Disingkat] \\ ${ }^{1}$ Nama Institusi (penulis 1, times new roman 11) \\ email: penulis_1@abc.ac.id (times new roman 11) \\ ${ }^{2}$ Nama Institusi (penulis 1 , times new roman 11) \\ email: penulis_2@abc.ac.id (times new roman 11) \\ No. Handphone : \\ ${ }^{1}$ Nama Kota dan Negara (times new roman 11) \\ ${ }^{2}$ Nama Kota dan Negara (times new roman 11)
}

\section{ABSTRAK [Times New Roman 10, bahasa Indonesia]}

Abstrak ditulis dalam bahasa indonesia berisikan tujuan penelitian, metode/pendekatan penelitian dan hasil penelitian. Abstrak ditulis dalam satu alenia, tidak lebih dari 200 kata. (Times New Roman 10, spasi tunggal).

Kata kunci: 3-5 kata kunci dipisahkan dengan tanda koma. [Font Times New Roman 10, spasi tunggal].

\section{ABSTRACT [Times New Roman 10, bahasa Inggris]}

Abstrak ditulis dalam bahasa Inggris yang berisikan tujuan penelitian, metode/pendekatan penelitian dan hasil penelitian. Abstrak ditulis dalam satu alenia, tidak lebih dari 200 kata. (Times New Roman 10, spasi tunggal).

Keywords: 3-5 kata kunci dipisahkan dengan tanda koma. [Font Times New Roman 10, spasi tunggal]

\section{PENDAHULUAN [Times New Roman 12 bold]}

Pendahuluan (berisi latar belakang, konteks penelitian, hasil kajian pustaka, dan tujuan penelitian, yang semuanya dipaparkan secara terintegrasi dalam bentuk paragraf-paragraf, dengan persentase 15-20\% dari keseluruhan artikel) Tinjauan pustaka yang relevan dan pengembangan hipotesis (jika ada) dimasukkan dalam bagian ini. [Times New Roman, 12, normal].

\section{METODE}

Metode menjelaskan paparan dalam bentuk paragraf tentang rancangan penelitian, sumber data, teknik pengumpulan data, dan analisis data yang secara nyata dilakukan peneliti, dengan persentase $10-15 \%$ [Times New Roman, 12, normal].

\section{HASIL DAN PEMBAHASAN}

Hasil penelitian berisi paparan hasil analisis yang berkaitan dengan pertanyaan penelitian, sedangkan pembahasan berisi pemaknaan hasil dan perbandingan dengan teori dan/atau hasil penelitian sejenis, dengan persentase 40$60 \%$ dari keseluruhan artikel); Kemungkinan tindak lanjut kegiatan dapat juga disampaikan pada bagian ini Hasil penelitian dapat dilengkapi dengan tabel 1 
(bukan tabel berikut: ), grafik/gambar 1 (bukan grafik/gambar berikut: ), dan/atau bagan 1 (bukan bagan berikut: ). [Times New Roman, 12, normal].

Tabel 1. Nama Tabel (contoh tabel 1)

\begin{tabular}{lccc}
\hline & & \multicolumn{2}{c}{ 95\%CI } \\
\cline { 3 - 4 } Condition & $M(S D)$ & LL & UL \\
\hline Letters & $14.5(28.6)$ & 5.4 & 23.6 \\
Digits & $31.8(33.2)$ & 21.2 & 42.4 \\
\hline
\end{tabular}

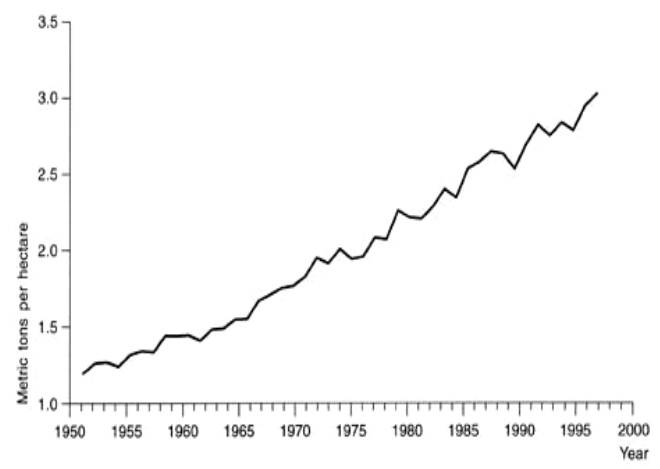

Gambar 1. Nama gambar (contoh gambar 1)

\section{SIMPULAN}

Berisi temuan penelitian yang berupa jawaban atas pertanyaan penelitian atau berupa intisari hasil pembahasan, yang disajikan dalam bentuk paragraf . Saran dapat disampaikan pada bagian ini [Times New Roman, 12, normal].

\section{DAFTAR PUSTAKA}

Penulisan pustaka hanya yang disitasi hanya dalam naskah ini dan diurutkan secara alfabetis dan kronologis.

\section{Buku:}

Gardner, H. 1993. Multiple Intelligences. New York: BasicBooks.

\section{Buku kumpulan artikel:}

Wahyono, P dan Sugiarti (Eds.). 2013. Pencerahan Pendidikan Masa Depan. Malang: UMM Press

\section{Artikel dalam buku kumpulan artikel:}

Bezooijen, R. V. 2002. Aesthetic evaluation of Dutch: Comparison across dialects, accents and languages. Dalam D. Long, \& D. R. Preston (Eds.), Handbook of perceptual dialectology (Vol. 2, hlm. 13-30). Amsterdam and Philadelphia: Benjamins.

\section{Artikel dalam jurnal atau majalah:}

Jaber, M., \& Hussein, R. 2011. Native speakers' perception of non-native English speech. English Language Teaching, 4(4), 77-87.

\section{Dokumen resmi:}


Undang-undang Republik Indonesia Nomor 2 tentang Sistem Pendidikan Nasional. 2003. Surabaya: Usaha Nasional 


\section{TEMPLATES FOR ARTICLE JURNAL CIVIC HUKUM}

\section{General requirements}

1. The term "Article" in this book are articles of results research and study the libraries focus attention on citizenship issues, Character Education, Law, Politics, Anti-corruption Education, and Learning Citizenship.

2. The writer has the obligation to write and translate (into English) a matched letter stating that the article is the work of his/her own and has never been offered an opportunity to be published in other media.

3. The article can be uploaded and registered through the web page: http://ejournal.umm.ac.id/index.php/jurnalcivichukum/user/register

\section{Terms of Writing}

1. The language used in scriptwriting is Indonesian or English.

2. The script is typed on A4 paper with $4 \mathrm{~cm}$ left margin and $3 \mathrm{~cm}$ upper, lower and right margins, using Times New Roman letter type, 12 letter size, and space 1 .

3. The number of article pages is 10 to 15 pages.

4. Systematics of Writing:

a. TITLE [Times New Roman 14 bold]

Title writing is using short sentences, but adequate to describe the contents (substance) of the article as a whole. The title of Indonesian language consists of a maximum of 14 words, while the English title consists of a maximum of 12 words.

b. Author Name [Times New Roman 12 bold]

The name of the author is listed without a title, then accompanied by correspondence address (institution), and email address (email). If there are more than one author then the names are written in similar rule with the main author. For the main author, contactable mobile number is required.

c. ABSTRACT and Keywords [Times New Roman 10 bold]

Abstract consists of a maximum of 200 words. Abstract reflects problems, objectives, research methods, results and suggestions. Abstracts are written in both Indonesian and English, using Times New Roman font size 10, space 1. Keywords are arranged alphabetically, reflecting the essence on the content of the article, generated in 3-5 words / phrases.

d. INTRODUCTION [Times New Roman 12 bold]

Introduction should contain backgrounds, research contexts, literature review results, and research objectives; all described in an integrated manner in the form of paragraphs with a percentage of $15-20 \%$ of the whole article. The 
relevant literature review and hypothesis development (if any) are included in this section. [Times New Roman, 12, normal].

e. METHOD [Times New Roman 12 bold]

The method describes the exposure in the form of a paragraph about the research design, data sources, data collection techniques, and data analysis that are actually conducted by the researcher with a percentage of $10-15 \%$ of the whole article [Times New Roman, 12, normal].

f. RESULTS AND DISCUSSION [Times New Roman 12 bold]

The result contains the result of the analysis related to the research question(s), while the discussion contains the meanings of the results and the comparison with theory and / or similar research results, with the percentage of 40-60\% of the whole article; possible follow-up activities can also be submitted in this section. The results of the research can be supplemented by table 1 (not the following table:), graph / image 1 (not the following graphic / image:), and / or chart 1 (not the following charts:). [Times New Roman, 12, normal].

Table 1. Name of the Table (example of table 1)

\begin{tabular}{lccc}
\hline & & \multicolumn{2}{c}{ 95\%CI } \\
\cline { 3 - 4 } Condition & $M(S D)$ & LL & UL \\
\hline Letters & $14.5(28.6)$ & 5.4 & 23.6 \\
Digits & $31.8(33.2)$ & 21.2 & 42.4 \\
\hline
\end{tabular}

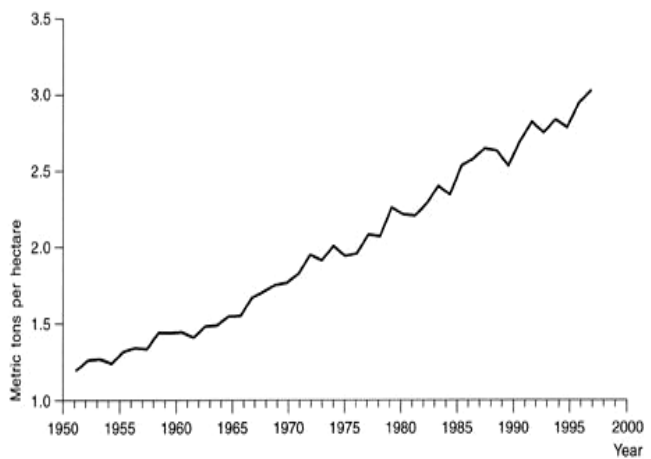

Figure 1. Name of Figure(example offigure 1)

g. CONCLUSION [Times New Roman 12 bold]

Contains research findings in the form of answers to research questions or in the form of a summary of the results of the discussion, presented in paragraph form. Suggestions can be given in this section [Times New Roman, 12, normal].

h. Bibliography.

Bibliography is written in a systematic and written sequentially in alphabetical order. The comma punctuation is replaced with full-stop punctuation marks; no citation page is included; quotes contained in the body 
of the articles must be listed in the bibliography as well as the opposite quote that is in the bibliography must exist in the article.

Reference of Book:

Noddings, N. 1993. Educating for Intelligent Belief or Unbelief. New York: Teacher College Press.

Reference of ArticleinBooks Articles:

Margono. 2008. Manajemen Jurnal Ilmiah. Dalam M.G Waseso \& A. Saukah (Eds.), Menerbitkan Jurnal Ilmiah (hlm. 46-50). Malang: UMM Press.

Reference of Editorial Book:

Rusli, Marah. 2005. Sosiologi Pendidikan: Kajian Berdasarkan Teori Integritas Mikro-Makro (Arnaldi. S Ed.) Malang: UMM Press.

Reference of Book Originating from Electronic Library:

Dealey, C. 1998. The Care of Wounds: A Guide for Nurses. Oxford: Blackwell Science. From NetLibrary, (Online), (http://netlibrary.com), accessed on 26 Agustus 2012.

Referenceof Articles from Internet Based Printed Journals:

Mappiare-AT, A., Ibrahim, A.S. \& Sudjiono. 2009. Budaya Komunikasi RemajaPelajar di Tiga Kota Metropolitan Pantai Indonesia. Jurnal Ilmu Pendidikan, (Online), 16 (1): 12-21, (http://www.umm.ac.id) accessed on 28 October 2009

\section{Reference of Articles from CD-ROM Journals:}

Krashen, S., Long, M. \& Scarcella, R. 2007. Age, Rate and Eventual Attainment in Second Language Acquisition. TESOL Quarterly, 13: 543-567 (CDROM: TESOL Quarterly-Digital, 2007).

Reference of Article in Journal or Magazine:

Wentzel, K. R. 1997. Student Motivation in Middle School: The Role of Perceived Pedagogical Caring. Journal of Educational Psychology, 89 (3), 411-419.

\section{Reference of Translated Book:}

Habermas ,Jurgen. 2007. TeoriTindakanKomunikatif II: Kritikatas Rasio Fungsionaris. Translated by Nurhadi. Yogyakarta: Kreasi Wacana.

References of Official Government Documents issued by Institution:

Undang-Undang Sistem Pendidikan Nasional (UURI No. 20 Tahun 2003 dan Peraturan Pelaksanaannya. 2003. Jakarta: Departemen Pendidikan Nasional. 
Reference of Article in Newspaper with no Author:

JawaPos, 27 May 2015. “Komitmen Mendikbud Segarkan Pramuka”. page 3.

\section{Reference of Article from the Internet:}

Winingsih, H. Lucia, et. al. 2007. Peningkatan Mutu, Relevansi dan Daya Saing Pendidikan. Jakarta: Pusat Dokumentasi dan Informasi Ilmiah-Lembaga Ilmu Pengetahuan Indonesia PDII-LIPI, accessed on 2 December 2014 online www.Pdii.lipi.go.id/katalog/index.php/search catalog /byld/257453.

\section{Reference of Thesis or Dissertation:}

Mulyana, Yoyo. 2000. Keefektifan Model Mengajar Respons Pembaca dalam Pengajaran Pengkajian Puisi. Unpublished Dissertation. Bandung: Fakultas Fakultas Bahasa dan Seni Universitas Pendidikan Indonesia.

Musaffak. 2013. Peningkatan Kemampuan Membaca Kritis dengan Menggunakan Metode Mind Mapping. Unpublished Thesis. Malang: PPs UM.

5. The reference library used is a maximum of 10 years old with a minimum references of 10 articles and at least $50 \%$ of the references are from scientific journals.

6. The editor reserves the right to change the text of the manuscript insofar it does not affect the material or the content of the subject matter.

7. Anything involving licensing of quotations or the use of computer software for the making of manuscripts or other matters relating to the intellectual property rights of the author of the article, including the legal consequences which may arise, shall be the sole responsibility of the author of the article. 


\title{
TITLE WRITTEN WITH \\ FONT TIMES NEW ROMAN 14 BOLD (MAXIMUM OF 14 WORDS)
}

\author{
Author1 $^{1)}$, Author2 ${ }^{2)}$ etc. [Font Times New Roman 12, no title, \\ No abbreviation and acronym] \\ ${ }^{1}$ Institution (author 1, times new roman 11) \\ email: author_1@abc.ac.id (times new roman 11) \\ ${ }^{2}$ Institution (author 1, times new roman 11) \\ email: author_2@abc.ac.id (times new roman 11) \\ No. Handphone : \\ ${ }^{1}$ City and Country Name (times new roman 11 ) \\ ${ }^{2}$ City and Country Names (times new roman 11 )
}

\begin{abstract}
ABSTRAK [Times New Roman 10, bahasa Indonesia]
Abstrak ditulis dalam bahasa indonesia berisikan tujuan penelitian, metode/pendekatan penelitian dan hasil penelitian. Abstrak ditulis dalam satu alenia, tidak lebih dari 200 kata. (Times New Roman 10, spasi tunggal).
\end{abstract}

Kata kunci: 3-5 kata kunci dipisahkan dengan tanda koma. [Font Times New Roman 10, spasi tunggal].

ABSTRACT [Times New Roman 10, English]

The abtract is written in English, consists of the purposes of the research, method/approach of research and result of the research. Abstract is written in onealinea, with maximum of 200 words. (Times New Roman 10, single spaced).

Keywords: 3-5keywords separated with comma. [Times New Roman 10, single spaced]

\section{INTRODUCTION [Times New Roman 12 bold]}

Introduction(contains the background, the research context, the results of the literature review, and the research objectives, all described in an integrated form of paragraphs, with a percentage of $15-20 \%$ of the whole article) Relevant literature review and hypothesis development (if any). [Times New Roman, 12, normal spaced].

\section{METHOD}

The method describes the exposure in the form of paragraphs about the research design, data sources, data collection techniques, and data analysis conducted by researcher(s), with percentage of 10-15\% [Times New Roman, 12, normal spaced].

\section{RESULT AND DISCUSSION}

The result of the research contains the result of the analysis related to the research question, while the discussion contains the meanings of the results and the comparison with theory and / or similar research results, with the percentage of 40-60\% of the whole article); Possible follow-up activities can also be submitted in this section The results of the study can be supplemented by table 1 (not the following table:), graph / image 1 (not the following graphic / image:), and / or chart 1 (not the following chart:). [Times New Roman, 12, normal spaced]. 


\begin{tabular}{lccc}
\hline & & \multicolumn{2}{c}{ 95\%CI } \\
\cline { 3 - 4 } Condition & $M(S D)$ & LL & UL \\
\hline Letters & $14.5(28.6)$ & 5.4 & 23.6 \\
Digits & $31.8(33.2)$ & 21.2 & 42.4 \\
\hline
\end{tabular}

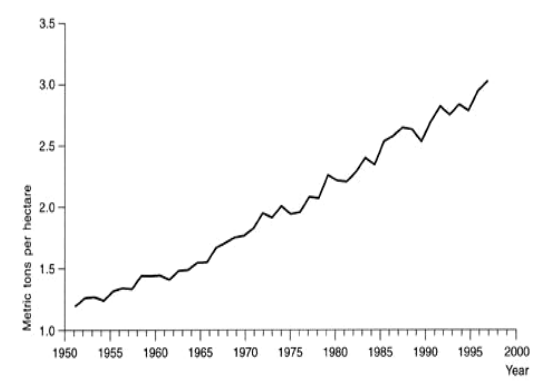

Figure 1. Name ofFigure (Example of Figure 1)

\section{CONCLUSION}

The conclusion contains research findings in the form of answers to research questions or in the form of a summary of the results of the discussion, presented in paragraph form. Suggestions can be given in this section [Times New Roman, 12, normal spaced].

\section{REFERENCES}

References consist of sources that are cited on this text and sorted alphabetically and chronologically.

\section{Book:}

Gardner, H. 1993. Multiple Intelligences. New York: BasicBooks.

\section{Book of Article Collection:}

Wahyono, P danSugiarti (Eds.). 2013. PencerahanPendidikanMasaDepan. Malang: UMM Press

\section{Articles in a Collection of Articles:}

Bezooijen, R. V. 2002. Aesthetic evaluation of Dutch: Comparison across dialects, accents and languages. Dalam D. Long, \& D. R. Preston (Eds.), Handbook of perceptual dialectology (Vol. 2, pg. 13-30). Amsterdam and Philadelphia: Benjamins.

\section{Articles in Journal or Magazine:}

Jaber, M., \& Hussein, R. 2011. Native speakers' perception of non-native English speech. English Language Teaching, 4(4), 77-87.

\section{Official Documents:}

Undang-undangRepublik Indonesia Nomor 2 tentangSistemPendidikanNasional. 2003. Surabaya: Usaha Nasional 